\title{
Examination of Job Satisfaction and Anxiety Levels of Workers Working at COVID-19 Diagnostic Centers During the Pandemic
}

\author{
Ümmühan KILIÇ ${ }^{1}$
}

Özlem GÜDÜK ${ }^{2 *}$

Özden GÜDÜK ${ }^{3}$

Sevinç GÖKÜZ ${ }^{4}$

Kılıç, Ü., Güdük, Ö., Güdük, Ö., Göküz, S. (2021). Examination of job satisfaction and anxiety levels of workers working at COVID-19 diagnostic centers during the pandemic. Journal of Health Systems and Policies (JHESP), 3,1-19.

\begin{abstract}
Health workers who are working in the front line during pandemic are vulnerable to mental health problems such as anxiety, which can affect their job satisfaction negatively. This study aims to determine the job satisfaction and anxiety levels of workers working in COVID19 diagnostic centers during the pandemic. The sample comprised of 184 biologists working in 17 diagnostic centers. A total of a 52 item questionnaire was applied to the employees consisting of questions about their demographic information, satisfaction level, and anxiety level. The data were analyzed with SPSS v.22.0. Nonparametric tests (i.e., Mann Withney U Test and Kruskal

\footnotetext{
${ }^{1}$ Samsun Provincial Health Directorate

${ }^{2}$ Fatih Sultan Mehmet Training and Research Hospital

${ }^{3}$ Yüksek İhtisas University

${ }^{4}$ Health Institutes of Turkey

*Corresponding author: Ö.GÜDÜK, gudukozlem@gmail.com
} 
Wallis Test) were used to determine the statistical significance of the comparative analysis results. Spearman correlation coefficient was used in the correlation analysis of job satisfaction and anxiety levels. Statistical significance was evaluated at $p<0.05$ level. The reliability of the scales was assessed through the Cronbach alpha coefficient.

The average age of the participants was $27.11 \pm 4.01$. Most of the participants were women $(71.7 \%)$, and $47.8 \%$ had a master's degree. $89 \%$ of participants voluntarily started this work during the pandemic process. $94.6 \%$ stated that they were committed to their profession, and $77.7 \%$ indicated that they were very suitable for the profession.

The anxiety level of the participants was found as average (mean=3.74 \pm 5.76 ). Gender and working hours affected the anxiety level. The anxiety level of women (4.31 \pm 6.02$)$ was significantly higher than men $(2.29 \pm 4.81)(\mathrm{p}=0,002)$. The highest anxiety level was in those who worked at the $4-12 \mathrm{pm}$ shift $(4.45 \pm 6.18)$. On the other hand, there was no statistically significant difference in anxiety levels according to education level, marital status, and working experience $(\mathrm{p}>0.05)$. The average job satisfaction of the participants was $4.18 \pm 0.61$. Committed employees had higher job satisfaction levels $(4.20 \pm 0.61)$ than others $(3.81 \pm 0.54)(p=0.026)$.

The study showed that although health workers work at high-risk units, the commitment to their job and being a volunteer for the job are very important to keep their anxiety levels lower and job satisfaction levels high.

Keywords: COVID-19 Outbreak, Health Workers, Anxiety, Job Satisfaction, Working Environment

\section{INTRODUCTION}

The coronavirus pandemic, which is also called the COVID-19 outbreak and emerged in China, has affected the whole world. It caused panic and mental problems in the community. Likewise, healthcare workers were also exposed to trauma. The risk of infection and the 
healthcare professionals' burden on preventing the pandemics can cause them to experience widespread mental disorders and post-traumatic stress disorders, including stress, anxiety, and depressive disorders. It puts healthcare personnel at risk and may cause anxiety in their work lives, too (Wu et al., 2020; Ekiz et al., 2020; Bao et al., 2020). In a study conducted by Sun and colleagues, with 442 healthcare workers in China in 2019, 89.4\% of the employees stated that they felt they were "at great risk" due to the COVID-19 outbreak. And they also stated that they were concerned about its results (Sun et al., 2020). Especially healthcare workers who work at high-risk units are more vulnerable than others (Lu et al., 2020).

It is reported that physical and psychological symptoms of anxiety and depression cause unsatisfactory work performance, and increasing the risk of accidents. Anxiety impacts on work. It affects work both at individual and organizational levels. At the individual employee level, this leads to impaired work performance, accidents and sickness absence. At the organizational level, there are likely to be effected on productivity, staff morale, accidents, absences, and staff turnover (Haslam et al., 2005).

Job satisfaction is defined as the employee's contentment of the employee from his/her job, a positive emotional response that it has achieved as due to self-assessment and work experience and developed against his/her work experience (Kahraman et al., 2011; Birgili et al, 2020). Job satisfaction is simply an indicator of how much the staff enjoys their job (Tambağ et al., 2015; Birgili et al, 2020). Individuals spend a significant amount of time of their lives at the workplace and integrate the traces of positive and negative experiences they encounter in this environment, both in the business environment and outside of work (Tekir et al., 2016). It is known that high job satisfaction increases the self-confidence, morale, performance, and efficiency of employees (Kaya and Oğuzöncül, 2016) and reduces the levels of illness, stress, tension, anxiety, complaints, absenteeism, and turnover (Nal and Nal, 2018). 
Many factors affect job satisfaction. These factors are grouped into two groups as individual and organizational factors. Age, gender, marital status, education, the position at work, professional seniority, character, intelligence, working years and similar factors are the individual elements (Çam and Yıldırım, 2010; Sevimli and İşcan et al., 2015). The quality of the job, management style, superintendence, organizational communication, development and promotion opportunities, wages, competition, organizational climate, working conditions, and similar factors also constitute organizational factors (Tekir et al., 2016; Nal and Nal, 2018). The effect of these risk factors on job satisfaction cannot be denied. Working conditions and the quality of the work together play an important role in the individuals' high job satisfaction . The high level of disease severity among employees working in health institutions increases anxiety and reduces job satisfaction (Yüksel et al., 2016). One of the critical examples of disease severity is the coronavirus outbreak.

Because job satisfaction among health care workers is an important essential factor for achieving the appropriate high-quality medical service (Said and El-Shafei, 2020), it has been a much-discussed topic. And it is desired to be as high as possible among the employees (Wicker, 2011).

Since the importance of their role during this pandemic, healthcare workers need to maintain their psychological and mental health. Those should be monitored carefully and make preventative studies if necessary, as it may lead to dangers that exceed the outbreak's consequences (Bao et al., 2020). Of course, it is important to determine these issues before implementing practices to reduce anxiety and improve job satisfaction. In this context, this study aims to determine the job satisfaction and anxiety levels of workers working in COVID19 diagnostic centers during the pandemic. The research questions of the study were defined as follows; 
- Do the anxiety levels of healthcare workers working in the front line during the pandemic differ according to demographic or working conditions?

- Do healthcare workers' job satisfaction levels working in the front line during the pandemic vary according to demographic or working conditions?

- Do the anxiety levels of healthcare workers working in the front line during the pandemic affect their job satisfaction?

\section{METHODOLOGY}

This is a cross-sectional study conducted in 17 diagnostic centers. Diagnostic centers play a fundamental role in diagnosing COVID-19 positive individuals during the pandemic. Samples taken from patients with suspected COVID-19 are sent to these centers, and employees (biologists and molecular biologists) conduct PCR tests on those samples. The centers have stringent rules to work. It is mandatory to wear personal protective equipment. Only the authorised staff is allowed to go in there. All samples are considered to may be infected. Therefore those centers are considered high-risk workplaces during the pandemic.

Population and Sample: The people of the study consisted of 201 biologists and molecular biologists who work at diagnostic centers, which were established to perform diagnostic tests during the outbreak. The centers have 201 employees, who were the population of the study. The study aimed to reach the whole population, so the sample size was not studied. Finally, we reached 184 biologists and molecular biologists who agreed to participate in the study ( $92 \%$ of the population). All the participants were informed about the study, and their written consents were obtained. "Not being voluntary" was determined as the exclusion criteria.

Data Collection Method and Tools: A questionnaire consisting of 52 questions and three sections was used to collect data in the study. The first part consisted of the demographic 
information of the participants and the statements about their working conditions. In the second and third parts, the Minnesota Satisfaction Questionnaire and the Beck Anxiety Scale were used to measure the job satisfaction and anxiety levels of participants, respectively.

The Minnesota Satisfaction Questionnaire: The scale was developed by Weiss et al. (Weiss et al., 1967) to measure job satisfaction and consists of a 5-point Likert-type of 20 items in total (Cronbach alpha=0.77). It was translated into Turkish by Baycan (Baycan, 1985). Within each item, five points describe the degree of satisfaction one feels about his job (1-"very dissatisfied", 2-"dissatisfied", 3-"can't decide if I'm satisfied or dissatisfied", 4-"satisfied" and 5-"very satisfied"). The result is calculated by taking the average of the scale; the lower the score, the lower the level of job satisfaction.

The Beck Anxiety Inventory: This scale was developed by Beck et al. (1988) to measure healthcare professionals' level of anxiety and consists of 21 items. It was translated into Turkish by Ulusoy. Turkish adaptation of the scale has high reliability (Cronbach alpha=0.93) (Ulusoy et al., 1998). Participants should rate the items according to their experience over the past week. Each item is rated on a 4 point scale ranging from 0 (not at all)3 (severely). The score range varies between 0-63.

Ethical committee approval was obtained for the study, dated 03.06.2020 and numbered 117. There is no conflict of interest between the authors in the study.

Analyses: The data were evaluated with SPSS v.22.0 (IBM Corp., Armonk, NY). The normality test (i.e., compatibility to the normal distribution) of the scales and subscales were evaluated with the Kolmogorov-Smirnov test. Since the normality assumption was invalid, nonparametric tests (i.e., Mann Withney U Test and Kruskal Wallis Test) were preferred to determine the statistical significance of the comparative analyses' results. Spearman rank 
coefficient was used in the correlation analysis of job satisfaction and anxiety levels. Statistical significance was evaluated at $\mathrm{p}<0.05$ level.

\section{RESULTS}

Before starting to analyze, the surveys' reliability (i.e., the Minnesota Satisfaction Questionnaire and the Beck Anxiety Inventory) was evaluated through the Cronbach alpha coefficient. In the study, the Cronbach alpha coefficients for the Minnesota Satisfaction Questionnaire and the Beck Anxiety Inventory were determined as 0.931 and 0.897 , respectively.

Descriptive findings of the biologists and molecular biologists participating in the study are given in Table 1. A total of 184 employees participated in the research. Most of the participants were women $(71.7 \%)$, and $28.3 \%$ were men. Among the participants $87 \%$ were single, and $13.0 \%$ were married. The participants' average age was 27.11 years $( \pm 4.01)$ and the most populated age group was the 21-25 age range (44.6\%). When they were asked about their profession's choice, except for only one participant, all of them stated that it was their own preferences. Considering the educational status of the employees, it was seen that $47.8 \%$ of them had a master's degree. Just above than half of the sample (52.7\%) did not have previous working experience before this job. And among those who had a working experience, $34.3 \%$ had less than a 4-year working experience before their present position. $89.01 \%$ of the participants stated that they started working voluntarily at COVID-19 diagnostic centers during the pandemic. According to participants' statements, $94.6 \%$ thought that they committed to their profession, $77.7 \%$ felt that they were very suitable for their career, $43.5 \%$ stated that the most efficient time to work during a day is between 8 am-4 pm (Table 1). 
Table 1: Descriptive Features of the Participants

\begin{tabular}{|c|c|c|c|}
\hline \multicolumn{2}{|l|}{ Variable } & \multirow{2}{*}{$\begin{array}{c}\text { Number } \\
132 \\
\end{array}$} & \multirow{2}{*}{$\begin{array}{c}\% \\
71,7\end{array}$} \\
\hline \multirow{2}{*}{ Gender } & Female & & \\
\hline & Male & 52 & 28,3 \\
\hline \multirow{3}{*}{ Age } & 21-25 years & 82 & 44,6 \\
\hline & 26-30 years & 70 & 38,0 \\
\hline & +31 years & 31 & 16,9 \\
\hline \multirow{3}{*}{ Education Level } & Bachelor's Degree & 61 & 33,2 \\
\hline & Master's Degree & 88 & 47,8 \\
\hline & Doctorate $(\mathrm{PhD})$ & 35 & 19,0 \\
\hline \multirow{2}{*}{ Marital Status } & Married & 24 & 13,0 \\
\hline & Single & 160 & 87,0 \\
\hline \multirow{2}{*}{ Existence of Working Experience } & Yes & 87 & 47,3 \\
\hline & No & 97 & 52,7 \\
\hline \multirow{4}{*}{ Working Experience (Years) } & None & 97 & 52,7 \\
\hline & Less than 1 year & 29 & 15,8 \\
\hline & $1-4$ years & 34 & 18,5 \\
\hline & More than 4 years & 22 & 12,0 \\
\hline \multirow{3}{*}{ Reason of Working } & Volunteer & 164 & 89,01 \\
\hline & Economic conditions & 18 & 9,8 \\
\hline & For career & 2 & 1,1 \\
\hline \multirow{4}{*}{ Efficient Shift (Hours) } & $8 \mathrm{am}-4 \mathrm{pm}$ & 80 & 43,5 \\
\hline & $4 \mathrm{pm}-12 \mathrm{pm}$ & 47 & 25,5 \\
\hline & $12 \mathrm{pm}-8 \mathrm{am}$ & 16 & 8,7 \\
\hline & All the same & 41 & 22,3 \\
\hline \multirow{4}{*}{ Appropriateness of Profession } & Not Appropriate & 1 & 0,5 \\
\hline & Partially Appropriate & 4 & 2,2 \\
\hline & Appropriate & 36 & 19,6 \\
\hline & Very Appropriate & 143 & 77,7 \\
\hline \multirow{2}{*}{ Commitment to Profession } & Committed & 174 & 94,6 \\
\hline & Partly Committed & 10 & 5,4 \\
\hline
\end{tabular}

As can be seen in Table 2, whether there was a difference in job satisfaction and anxiety levels according to age, education and shift hours of the employees analyzed with Kruskal Wallis Test. Job satisfaction was examined under three sub-dimensions (internal, external, and total). According to all variables, there was no statistical difference in job satisfaction subdimensions $(p>0.05)$. There was no statistical difference in any sub dimensions of job satisfaction according to all variables $(\mathrm{p}>0.05)$. 
When it was evaluated in terms of anxiety level, it was found that there was no significant difference in age and education level ( $p>0.05)$. However, there was a substantial significant difference between shift hours that the employees considered the most efficient $(\mathrm{p}=0.009)$. Among these groups, the group who thought that all shift hours were the same

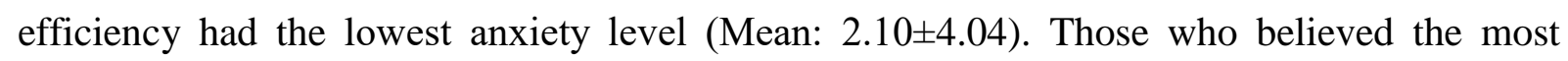
efficient shift was between 4 pm-12 pm had the highest anxiety level (Mean: 4.45 \pm 6.18 ).

When the job satisfaction and anxiety levels of the employees participating in the study were evaluated, there was no significant difference in both total job satisfaction and its subdimensions in terms of gender $(p>0.05)$. However, there was a significant difference in anxiety levels $(\mathrm{p}=0.002)$. It was observed that women's anxiety level (Mean: 4.31 \pm 6.02 ) was higher than men's (Mean: 2.29 \pm 4.81 ).

In terms of the employees' professional commitment status, there was a significant difference in job satisfaction levels $(\mathrm{p}=0.026)$. This difference was the result of internal satisfaction levels $(\mathrm{p}=0.014)$. Committed employees' job satisfaction was higher than partly committed employees' job satisfaction (Mean: 4.20 \pm 0.61 ; Mean: 3.81 \pm 0.54 , respectively). 
Table 2: Evaluation of Participants' Job Satisfaction and Anxiety Levels According to Age, Education, Shift Hours

\begin{tabular}{|c|c|c|c|c|c|c|c|c|c|c|c|c|c|c|c|c|}
\hline & \multicolumn{4}{|c|}{ Job Satisfaction (İnternal) } & \multicolumn{4}{|c|}{ Job Satisfaction (External) } & \multicolumn{4}{|c|}{ Job Satisfaction (Total ) } & \multicolumn{4}{|c|}{ Anxiety (Beck) } \\
\hline & $\mathbf{n}$ & Mean \pm SD & $\begin{array}{l}\text { Mean } \\
\text { Rank }\end{array}$ & $\mathbf{p}$ & $\mathbf{n}$ & Mean \pm SD & $\begin{array}{l}\text { Mean } \\
\text { Rank }\end{array}$ & $\mathbf{p}$ & $\mathbf{n}$ & Mean \pm SD & $\begin{array}{l}\text { Mean } \\
\text { Rank }\end{array}$ & $\mathbf{p}$ & $\mathbf{n}$ & Mean \pm SD & $\begin{array}{l}\text { Mean } \\
\text { Rank }\end{array}$ & $\mathbf{p}$ \\
\hline \multicolumn{17}{|l|}{ Age } \\
\hline $21-25$ & 82 & $4,29 \pm 0,55$ & 95,96 & \multirow{3}{*}{0,653} & 82 & $4,08 \pm 0,75$ & 92,45 & \multirow{3}{*}{0,453} & 82 & $4,21 \pm 0,59$ & 94,45 & \multirow{3}{*}{0,775} & 82 & $4,18 \pm 6,48$ & 94,98 & \multirow{3}{*}{0,775} \\
\hline $26-30$ & 70 & $4,21 \pm 0,61$ & 89,31 & & 70 & $4,05 \pm 0,66$ & 87,26 & & 70 & $4,15 \pm 0,60$ & 88,02 & & 70 & $3,53 \pm 5,39$ & 89,68 & \\
\hline 31 and + & 31 & $4,15 \pm 0,68$ & 87,58 & & 31 & $4,20 \pm 0,73$ & 101,52 & & 31 & $4,17 \pm 0,68$ & 94,50 & & 31 & $3,16 \pm 4,61$ & 89,37 & \\
\hline \multicolumn{17}{|l|}{ Education } \\
\hline Bachelor & 61 & $4,25 \pm 0,49$ & 89,93 & \multirow{3}{*}{0,112} & 61 & $4,04 \pm 0,69$ & 88,29 & \multirow{3}{*}{0,265} & 61 & $4,16 \pm 0,53$ & 88,68 & \multirow{3}{*}{0,136} & 61 & $4,77 \pm 7,09$ & 100,19 & \multirow{3}{*}{0,150} \\
\hline Master' & 88 & $4,31 \pm 0,61$ & 99,87 & & 88 & $4,16 \pm 0,74$ & 98,97 & & 88 & $4,25 \pm 0,64$ & 100,07 & & 88 & $2,82 \pm 4,47$ & 84,91 & \\
\hline Doctorate & 35 & $4,05 \pm 0,68$ & 78,46 & & 35 & $4,01 \pm 0,64$ & 83,59 & & 35 & $4,03 \pm 0,64$ & 80,11 & & 35 & $4,26 \pm 5,87$ & 98,17 & \\
\hline \multicolumn{17}{|l|}{ Shifts } \\
\hline 8 am-4 pm & 80 & $4,26 \pm 0,53$ & 92,57 & \multirow{4}{*}{0,861} & 80 & $4,08 \pm 0,69$ & 91,46 & \multirow{4}{*}{3,862} & 80 & $4,19 \pm 0,55$ & 91,74 & & 80 & $4,31 \pm 6,42$ & 96,66 & \multirow{4}{*}{0,009} \\
\hline $4 \mathrm{pm}-12 \mathrm{pm}$ & 47 & $4,20 \pm 0,55$ & 87,37 & & 47 & $4,03 \pm 0,63$ & 84,74 & & 47 & $4,13 \pm 0,56$ & 85,93 & & 47 & $4,45 \pm 6,18$ & 104,10 & \\
\hline $12 \mathrm{pm}-8 \mathrm{am}$ & 16 & $4,25 \pm 0,57$ & 93,53 & & 16 & $4,30 \pm 0,65$ & 110,16 & & 16 & $4,27 \pm 0,58$ & 102,47 & 0,640 & 16 & $3,00 \pm 4,02$ & 97,53 & \\
\hline $\begin{array}{l}\text { All of the } \\
\text { same }\end{array}$ & 41 & $4,24 \pm 0,76$ & 97,84 & & 41 & $4,09 \pm 0,85$ & 96,52 & & 41 & $4,18 \pm 0,77$ & 97,63 & & 41 & $2,10 \pm 4,04$ & 69,13 & \\
\hline
\end{tabular}

*Kruskal-Wallis Analysis 
According to marital status and past working experience, there was no statistically significant difference between groups in both anxiety and job satisfaction levels ( $>0.05$ ) (Table 3).

Table 3: Evaluation of Participants' Job Satisfaction and Anxiety Levels According to Gender, Marital Status, Professional Commitment \& Work Experience

\begin{tabular}{|c|c|c|c|c|c|c|c|c|c|c|c|c|c|c|c|c|}
\hline \multirow[t]{2}{*}{ Variable } & \multicolumn{4}{|c|}{ Job Satisfaction (İnternal) } & \multicolumn{4}{|c|}{ Job Satisfaction (External) } & \multicolumn{4}{|c|}{ Job Satisfaction (Total ) } & \multicolumn{4}{|c|}{ Anxiety (Beck) } \\
\hline & $\mathbf{n}$ & Mean \pm SD & $\begin{array}{l}\text { Mean } \\
\text { Rank }\end{array}$ & $\mathbf{p}$ & $\mathbf{n}$ & Mean \pm SD & $\begin{array}{l}\text { Mean } \\
\text { Rank }\end{array}$ & $\mathbf{p}$ & $\mathbf{n}$ & Mean \pm SD & $\begin{array}{l}\text { Mean } \\
\text { Rank }\end{array}$ & $\mathbf{p}$ & $\mathbf{n}$ & Mean \pm SD & $\begin{array}{l}\text { Mean } \\
\text { Rank } \\
\end{array}$ & $\mathbf{p}$ \\
\hline \multicolumn{17}{|l|}{ Gender } \\
\hline Female & 132 & $4,29 \pm 0,54$ & 95,39 & \multirow{2}{*}{0,239} & 132 & $4,15 \pm 0,66$ & 96,06 & \multirow{2}{*}{0,147} & 132 & $4,23 \pm 0,56$ & 96,24 & \multirow{2}{*}{0,129} & 132 & $4,31 \pm 6,02$ & 99,76 & \multirow{2}{*}{$\mathbf{0 , 0 0 2}$} \\
\hline Male & 52 & $4,11 \pm 0,71$ & 85,15 & & 52 & $3,94 \pm 0,81$ & 83,46 & & 52 & $4,04 \pm 0,70$ & 83,01 & & 52 & $2,29 \pm 4,81$ & 74,08 & \\
\hline \multicolumn{17}{|c|}{ Marrital Status } \\
\hline Married & 24 & $4,16 \pm 0,64$ & 85,69 & \multirow{2}{*}{0,501} & 24 & $4,17 \pm 0,67$ & 96,27 & \multirow{2}{*}{0,709} & 24 & $4,16 \pm 0,64$ & 90,44 & \multirow{2}{*}{0,839} & 24 & $5,79 \pm 7,08$ & 107,56 & \multirow{2}{*}{0,122} \\
\hline Single & 160 & $4,25 \pm 0,59$ & 93,52 & & 160 & $4,08 \pm 0,71$ & 91,93 & & 160 & $4,18 \pm 0,60$ & 92,81 & & 160 & $3,43 \pm 5,50$ & 90,24 & \\
\hline \multicolumn{17}{|c|}{ Commitment to Profession } \\
\hline Committed & 174 & $4,26 \pm 0,60$ & 94,82 & \multirow[b]{2}{*}{0,014} & 174 & $4,11 \pm 0,70$ & 94,19 & \multirow[b]{2}{*}{0,072} & 174 & $4,20 \pm 0,61$ & 94,59 & \multirow[b]{2}{*}{$\mathbf{0 , 0 2 6}$} & 174 & $3,22 \pm 5,08$ & 89,02 & \multirow[b]{2}{*}{$\mathbf{0 , 0 0 0}$} \\
\hline $\begin{array}{c}\text { Partly } \\
\text { Committed }\end{array}$ & 10 & $3,98 \pm 0,41$ & 52,20 & & 10 & $3,69 \pm 0,77$ & 63,15 & & 10 & $3,81 \pm 0,54$ & 56,15 & & 10 & $12,07 \pm 9,19$ & 153,00 & \\
\hline \multicolumn{17}{|c|}{ Existence of Working Experience } \\
\hline Yes & 87 & $4,20 \pm 0,59$ & 88,78 & \multirow{2}{*}{0,368} & 87 & $4,07 \pm 0,71$ & 90,09 & \multirow{2}{*}{0,560} & 87 & $4,15 \pm 0,61$ & 88,61 & \multirow{2}{*}{0,348} & 87 & $4,61 \pm 6,87$ & 97,80 & \multirow{2}{*}{0,182} \\
\hline No & 97 & $4,27 \pm 0,60$ & 95,84 & & 97 & $4,11 \pm 0,71$ & 94,66 & & 97 & $4,21 \pm 0,61$ & 95,98 & & 97 & $2,96 \pm 4,44$ & 87,74 & \\
\hline
\end{tabular}

*Mann-Whitney-U Analysis 
The relationship between the participants' anxiety levels and job satisfaction levels was examined with correlation analysis, and it was seen that there was a relationship between them $(\mathrm{p}<0.05)$. It was observed that the relationship was negative and low in all sub-dimensions $(\mathrm{r}=-$ 0.170, $\mathrm{r}=-0.312, \mathrm{r}=-0.245$ ) (Table 4). Which meant that as job satisfaction got decreased, the anxiety level got increased.

Table 4: Correlation Analysis of Job Satisfaction and Anxiety Levels

\begin{tabular}{|c|c|c|c|c|}
\hline \multicolumn{2}{|c|}{} & $\begin{array}{c}\text { Job Satisfaction } \\
\text { (Internal) }\end{array}$ & $\begin{array}{c}\text { Job Satisfaction } \\
\text { (External) }\end{array}$ & $\begin{array}{c}\text { Job Satisfaction } \\
\text { (Total) }\end{array}$ \\
\hline \multirow{3}{*}{ Anxiety } & $\mathrm{r}$ &,$- 170^{*}$ &,$- 312^{* *}$ &,$- 245^{* *}$ \\
\cline { 2 - 5 } & $\mathrm{p}$ & $\mathbf{, 0 2 1}$ & $\mathbf{, 0 0 0}$ & $\mathbf{0 0 1}$ \\
\cline { 2 - 5 } & $\mathrm{n}$ & 184 & 184 & 184 \\
\hline
\end{tabular}

$* p=0.05$

$* p=0.01$

\section{DISCUSSIONS AND CONCLUSIONS}

The infection risk and increased workload during the pandemic can cause healthcare workers to experience various mental disorders, including anxiety. This puts healthcare professionals at risk and can cause impaired work performance and the risk of accidents. In this study, we aimed to determine the job satisfaction and anxiety levels of biologists working in COVID-19 diagnostic centers and investigate the factors affecting them. In this context, a 52 expression/question questionnaire was applied to participants. Both descriptive and inferential statistics were conducted to analyze the job satisfaction and anxiety levels of biologists.

We observed that a young, educated, and the sensible population was employed in those centers. The participants' age average was $27.11( \pm 4.01)$, and the most populated age group was between 21-25 ages (44.6\%). In terms of the educational status of the employees, it was seen that $47.8 \%$ were graduates. $52.7 \%$ of employees had no previous work experience, and 
$18.5 \%$ of employees who had work experience had worked between 1-4 years. When they were asked about their profession's choice, almost all of them (except one employee) stated that it was their preference. Most of the employees stated that they were volunteers working at the centers during the pandemic. $94.6 \%$ thought that they commited to their profession, $77.7 \%$ were very suitable for their profession, $43.5 \%$ stated that the most efficient time to work between 8 a.m. and 4 p.m.

The average total anxiety level of the participants was $3.73 \pm 5.76$. Anxiety was moderate to severe in only 8 of 181 participants $(2.7 \%$ had moderate, and $1.6 \%$ had severe anxiety). In many studies with healthcare workers during the COVID-19 outbreak, anxiety levels were at medium or high levels. Zhang et al. (2020a) found the anxiety prevalence as $28 \%$, while Liu et al. (Liu et al., 2020) found that it was $44.7 \%$. In a study that health personnel was found to show symptoms of stress, depression, and anxiety; those symptoms were observed seriously, $2.2 \%$ to $14.5 \%$ of all participants (Bohlken et al., 2020). Zhang et al. (2020a) found that in $28 \%$ of employees, the level of anxiety was at a level that "it should be initiated a clinical interview to determine whether mental disorders were present". In a study conducted on frontline health employees, the overall prevalences of the low, medium, and severe anxiety levels were $10.35 \%$, $1.36 \%$, and $0.78 \%$, respectively (Liu et al., 2020). According to Chen et al. (2020), the general anxiety level of the healthcare professionals working in high-risk areas was $18.1 \%$ in general. It was observed that $10.5 \%$ had low, $5.7 \%$ had moderate, and $1.9 \%$ had high-level anxiety. In a study with healthcare workers in Bolivia, Peru, and Ecuador, low anxiety was found in $44 \%$, moderate in $18 \%$, and severe in 5\% (Zhang et al., 2020b). In another study, the anxiety level was found $11.4 \%$ in doctors and $27.9 \%$ in nurses working on the front line (Zhu et al., 2020). A systematic review of studies found that nurses had higher levels of anxiety and depression than other frontline healthcare workers (Labrague and De los Santos, 2020). Experiencing mental problems during outbreaks is not new for healthcare professionals. Indeed, during the 
SARS (Severe Acute Respiratory Syndrome) outbreak in 2003, moderate to high anxiety levels were detected in most healthcare workers (Chew et al., 2020). Likewise, Chong et al. (Chong et al., 2004) found that the level of anxiety during the SARS period was $77.4 \%$ in healthcare workers.

In this study, it was found that there was no difference in anxiety levels by age ( $p>0.05)$, in parallel to the findings of some previous studies (Liu et al., 2020; Chen et al., 2020). On the other hand, Zhang et al. (2020a) stated that the older staff had better mental health than others in their study. Similarly, there was no difference in anxiety levels according to education levels (p>0.05), which was compatible with the previous reports (Liu et al., 2020; Chen et al., 2020).

On the other hand, we identified a statistically significant difference in anxiety levels in terms of gender $(\mathrm{p}=0.002)$. The women's anxiety level (Mean: 4.31 \pm 6.02$)$ was significantly higher than that of men (Mean: $2.29 \pm 4.81$ ). In the majority of the previous studies, similar to our results, the level of anxiety in women was higher (Pappa et al., 2020; Zhang et al., 2020a, (Zhu et al., 2020; Lai et al., 2019; Zhang et al., 2020c; Zhu et al., 2020). On the other hand, some studies also reported that gender did not affect anxiety levels (Liu et al., 2020, Chen et al., 2020; Zhang et al., 2020d). When anxiety levels were analyzed in terms of marital status, there was no statistically significant difference between groups in this study ( $p>0.05)$. Similarly, previous studies did not found a significant difference in marital status (Zhang et al., 2020a; Liu et al., 2020; Chen et al., 2020).

One of the original aspects of this study was the analysis of anxiety levels according to shift hours, and we observed a significant difference in anxiety levels from this point. The employees who thought that all shift hours were the same had the lowest anxiety level (Mean: $2.10 \pm 4.04)$. On the other hand, those who believed that the most efficient shift was between 4

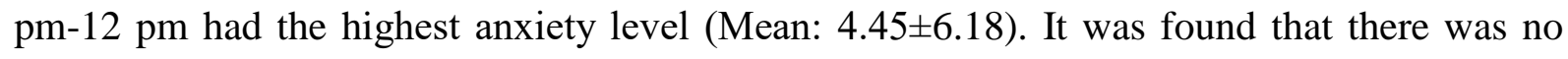


statistically significant difference in anxiety levels between the groups in terms of previous work experience $(\mathrm{p}>0.05)$.

It is known that healthcare workers' job satisfaction is moderate in general (Birgili et al., 2010; Leblebici ve Mutlu, 2014). Labrague and De Los Santos (2020), in their study with 261 nurses working in 5 hospitals in the Philippines, found nurses' job satisfaction at 3.65 ( $\mathrm{SD}=0.99$ ) during the COVID-19 outbreak. However, here, we showed that the participants' job satisfaction was significantly higher in the diagnostic centers since the average job satisfaction of the employees was $4.18 \pm 0.61$.

In this study, there was no difference in job satisfaction levels according to age, gender, education, and shift hours ( $p>0.05)$. Zhang et al. (2020e) found that job satisfaction was negatively impacted when the young staff's working time was extended. Chen et al. (2020b) found that older employees had higher job satisfaction, while gender and education did not affect it.

There was no difference between marital status and job satisfaction in this study ( $p>0.05$ ); similar results were obtained in other studies (Zhang et al., 2020a; Chen et al., 2020b).

Previous observations showed that the job satisfaction of those who love their profession is significantly higher than those who work for economic reasons (Birgili et al., 2010). In this study, a considerable proportion of the participants (94.6\%) expressed themselves as "committed to their profession." When the professional commitment status of the employees participating in the study was evaluated, it was found that there was a significant difference in job satisfaction levels between the groups $(\mathrm{p}=0.026)$; that difference was due to internal satisfaction ( $\mathrm{p}=0.014)$. Job satisfaction levels of committed employees' were higher than those who were partly committed (Mean: $4.20 \pm 0.61 ; 3.81 \pm 0.54$, respectively). 
There are differences in healthcare workers' anxiety levels according to whether they work in high-risk units or not. Employees working in high-risk units such as intensive care units, infectious disease clinics, and emergency units have higher anxiety, depression, and fear (Lu et al., 2020). On the other hand, in the study of Zhou et al. (Zhou et al., 2020), healthcare workers working in the front lines of COVID-19 prevention and treatment were found to have higher self-confidence due to better access to personal protective equipment (PPE). In a study conducted by Rubin et al. (2016) with the staff who went to work voluntarily in West Africa during the Ebola epidemic, only a few participants stated that they had psychological problems.

Even though COVID-19 Diagnosis Centers where this study was conducted were defined as high-risk units, it was thought the fact that the employees started working voluntarily $(89 \%)$, is committed to their profession $(94.6 \%)$, nd defining themselves as very appropriate to the profession $(77.7 \%)$ caused positive results in anxiety and job satisfaction levels.

Even though outbreaks affect all societies mental health, health workers are among the most negatively impacted groups. As can be seen in this study and previous studies, many factors affect the employees' anxiety and job satisfaction levels. Studies show that healthcare professionals' heavy workload and prolonged working times are some factors that affect their mental health during outbreaks.

Managers should carefully monitor the status of workers' mental health as it can positively or negatively affect employees' job performance. Healthcare managers should be aware of how their employees are affected during outbreaks, and they should be identified if there is a vulnerable group, and they support them better. On the other hand, it is thought that it would be beneficial to encourage the volunteers, who mentally better survived the process, to work in the front lines at the battle of outbreaks. 
Ethical Approval: This study was approved by the ethics committee of the Zeynep Kamil Women's and Pediatrics Training and Research Hospital (KAEK 03/06/2020-107).

Authors' Contributions: Concept: UK, SG, OG, OG -Design: UK, SG, OG - Resources: UK, SG, OG, OG - Data Collection: UK, SG - Analyse: OG, OG - Literature Rewiev: UK, OG,OG - Writing: UK, OG,OG - Critical review: OG, UK.

Funding and Acknowledgment: The authors declared that this study has received no financial support.

Conflict of Interest Statement: No conflict of interest was declared by the authors.

\section{REFERENCES}

Bao, Y., Sun, Y., Meng, S., Shi, J., Lu, L. (2020). 2019-nCoV epidemic: Address mental health care to empower society. The Lancet, 395,37-38.

Baycan, A. (1985). An analysis of the several aspects of job satisfaction between different occupational groups. Boğaziçi Üniversitesi, Sağllk Bilimleri Enstitüsü, İstanbul.

Birgili, F., Salış, F., Özdemir, S. (2010). Sağlık çalışanlarının iş doyumunu etkileyen bazı etmenlerin incelenmesi. Anadolu Hemşirelik ve Sağlık Bilimleri Dergisi, 13,27-37.

Bohlken, J., Schömig, F., Lemke, M. R., Pumberger, M., Riedel-Heller, S. G. (2020). COVID-19-Pandemie: Belastungen des medizinischen personals. Psychiatrische Praxis, 47,190-197.

Chen, X., Zhang, S. X., Jahanshahi, A. A., Alvarez-Risco, A., Dai, H., Li, J., Ibarra, V. G.(2020b). Belief in conspiracy theory about Covid-19 predicts mental health and well-being--a study of healthcare staff in ecuador. MedRxiv, 6,1-16.

Chen, Y., Zhou, H., Zhou, Y., Zhou, F. (2020a). Prevalence of self-reported depression and anxiety among pediatric medical staff members during the COVID-19 outbreak in Guiyang, China. Psychiatry research, 288, 11305 .

Chew, N. W., Lee, G. K., Tan, B. Y., Jing, M., Goh, Y., Ngiam, N. J., Sharma, A. K. (2020). A multinational, multicentre study on the psychological outcomes and associated physical symptoms amongst healthcare workers during COVID-19 outbreak. Brain, Behavior, and Immunity, 88,559-565.

Chong, M. Y., Wang, W. C., Hsieh, W. C., Lee, C. Y., Chiu, N. M., Yeh, W. C., Chen, C. L. (2004). Psychological impact of severe acute respiratory syndrome on health workers in a tertiary hospital. The British Journal of Psychiatry, 185,127-133.

Çam, O., Yıldırım, S. (2010). Hemşirelerde iş doyumu ve etkileyen faktörler. Türkiye Klinikleri Hemşirelik Bilimleri Dergisi, 2,64-70.

Ekiz, T., Ilıman, E., Dönmez, E. (2020). Bireylerin sağlık anksiyetesi düzeyleri ile Covid-19 salgını kontrol algısının karşılaş̧ııılması. Usaysad Dergisi, 6,139-154. 
Haslam, C., Atkinson, S., Brown, S. S., Haslam, R. A. (2005). Anxiety and depression in the workplace: Effects on the individual and organisation (a focus group investigation). Journal of Affective Disorders, 88,209-215.

Kahraman, G., Engin, E., Dülgerler, Ş., Öztürk, E. (2011). Yoğun bakım hemşirelerinin iş doyumları ve etkileyen faktörler. Dokuz Eylül Üniversitesi Hemşirelik Yüksekokulu Elektronik Dergisi, 4,12-18.

Kaya, F., Oğuzöncül. A. F. (2016). Birinci basamak sağlık çalışanlarında iş doyumu ve etkileyen faktörler. Dicle Tip Dergisi, 43,248-255.

Labrague, L. J., De los Santos, J. (2020). Fear of COVID-19, psychological distress, work satisfaction and turnover intention among front line nurses. Researchsquare, 1,1-9.

Lai, J., Ma, S., Wang, Y., Cai, Z., Hu, J., Wei, N., Tan, H. (2019). Factors associated with mental health outcomes among health care workers exposed to coronavirus disease. JAMA Network Open, 3,1-12.

Leblebici, Ö., Mutlu, S. (2014). Türkiye'de kamu sağlık çalışanlarının iş doyumlarının sağlıkta dönüşüm programı bağlamında incelenmesi. Hemşirelikte Araştırma Geliştirme Dergisi, 16,48-63.

Liu, C. Y., Yang, Y. Z., Zhang, X. M., Xu, X., Dou, Q. L., Zhang, W. W., Cheng, A. S. (2020). The prevalence and influencing factors in anxiety in medical workers fighting COVID-19 in China: A cross-sectional survey. Epidemiology \& Infection, 148,1-7.

Liu, S., Yang, L., Zhang, C., Xiang, Y. T., Liu, Z., Hu, S., Zhang, B. (2020). Online mental health services in China during the COVID-19 outbreak. The Lancet Psychiatry, 7,17-18.

Lu, W., Wang, H., Lin, Y., Li, L. (2020). Psychological status of medical workforce during the COVID-19 pandemic: A cross-sectional study. Psychiatry research, 288,1-5.

Nal, M., Nal, B. (2018). Sağlık çalışanlarının iş doyumu düzeylerinin incelenmesi: Bir kamu hastanesi örneği. ODÜ Sosyal Bilimler Araştırmaları Dergisi, 8,131-140.

Pappa, S., Ntella, V., Giannakas, T., Giannakoulis, V. G., Papoutsi, E., Katsaounou, P. (2020). Prevalence of depression, anxiety, and insomnia among healthcare workers during the COVID-19 pandemic: A systematic review and meta-analysis. Brain, Behavior, and Immunity, 88,901-907.

Rubin, G. J,. Harper, S., Williams, P. D., Öström, S., Bredbere, S., Amlôt, R., Greenberg, N. (2016). How to support staff deploying on overseas humanitarian work: A qualitative analysis of responder views about the 2014/15 West African Ebola outbreak. European Journal of Psychotraumatology, 7,1-12.

Said, R. M., El-Shafei, D. A. (2020). Occupational stress, job satisfaction, and intent to leave: Nurses working on front lines during COVID-19 pandemic in Zagazig City, Egypt. Environmental Science and Pollution Research, $28,1-11$.

Sevimli, F., İşcan, Ö. F. (2015). Bireysel ve iş ortamına ait etkenler açısından iş doyumu. Ege Akademik Bakış Dergisi, 5,55-64.

Sun, D., Yang, D., Li, Y., Zhou, J., Wang, W., Wang, Q., Zhang, Q. (2020). Psychological impact of 2019 novel coronavirus (2019-ncov) outbreak on health workers in China. Epidemiology and Infection, 148,1-17.

Tambağ, H., Kahraman, Y., Şahpolat, M., Can, R. (2015). Hemşirelerin çalışma ortamlarının iş doyumu üzerine etkisi. Bakırköy Tıp Dergisi, 11,143-149.

Tekir, Ö., Çevik, C., Arık, S., Çetin, G. (2016). Sağlık çalışanlarının tükenmişlik, iş doyumu düzeyleri ve yaşam doyumunun incelenmesi. Kırıkkale Üniversitesi Tıp Fakültesi Dergisi, 18,51-63.

Ulusoy, M., Sahin, N. H., Erkmen, H. (1998). The Beck anxiety inventory: Psychometric properties. Journal of Cognitive Psychotherapy, 12,163-172. 
Weiss, D. J., Dawis, R. V., England, G. W. (1967). Manual for the Minnesota Satisfaction Questionnaire. Minnesota Studies in Vocational Rehabilitation, 22,120-130.

Wicker, D. (2011). Job satisfaction: Fact or Fiction: Are you satisfied with your job? The USA: AuthorHouse.

Wu, Y., Wang, J., Luo, C., Hu, S., Lin, X., Anderson, A. E., Qian, Y. (2020). A comparison of burnout frequency among oncology physicians and nurses working on the front lines and usual wards during the COVID-19 epidemic in Wuhan, China. Journal of Pain and Symptom Management, 60,60-65.

Yüksel, K. C., Örsal, Ö., Köşgeroğlu, N. (2016). Hemşirelerde iş doyumu düzeyinin incelenmesi. Hemşirelikte Araştırma Geliştirme Dergisi, 18,1-12.

Zhang, S. X., Chen, J., Jahanshahi, A. A., Alvarez-Risco, A., Dai, H., LiJ, Patty-Tito, R.(2020e). Succumbing to the Covid-19 pandemic: Healthcare workers not satisfied and intend to leave their jobs. MedRxiv, 1-13.

Zhang, S. X., Liu, J., Jahanshahi, A. A., Nawaser, K., Li, J., Alimoradi, H. (2020a). When the storm is the strongest: The health conditions and job satisfaction of healthcare staff and their associated predictors during the epidemic peak of COVID-19. MedRxiv, 1-19.

Zhang, S. X., Liu, J., Jahanshahi, A. A., Nawaser, K., Yousefi, A., Li, J., Sun, S. (2020d). At the height of the storm: Healthcare staff's health conditions and job satisfaction and their associated predictors during the epidemic peak of COVID-19. Brain, Behavior, and Immunity, 87,144-146.

Zhang, S. X., Sun, S., Jahanshahi, A. A., Alvarez-Risco, A., Ibarra, V. G., Li, J., Patty-Tito, R., M. (2020b). Developing and testing a measure of Covid-19 organizational support of healthcare workers-results from Peru, Ecuador, and Bolivia. Psychiatry Research, 291,1-4.

Zhang, W. R., Wang, K., Yin, L., Zhao, W. F., Xue, Q., Peng, M., Chang, H. (2020c). Mental health and psychosocial problems of medical health workers during the COVID-19 epidemic in China. Psychotherapy and Psychosomatics, 89,242-250.

Zhou, M., Tang, F., Wang, Y., Nie, H., Zhang, L., You, G., Zhang, M. (2020). Knowledge, attitude and practice regarding COVID-19 among health care workers in Henan, China. Journal of Hospital Infection, 105,183-187.

Zhu, J., Sun, L., Zhang, L., Wang, H., Fan, A., Yang, B., Xiao, S. (2020). Prevalence and influencing factors of anxiety and depression symptoms in the first-line medical staff fighting against Covid-19 in Gansu. Frontiers in Psychiatry, 11,1-6.

Zhu, Z., Xu, S., Wang, H., Liu, Z., Wu, J., Li, G., Zhu, S. (2020). COVID-19 in Wuhan: Immediate psychological impact on 5062 health workers. MedRxiv, 1-16. 